Pesq. Vet. Bras. 36(2):131-135, fevereiro 2016 DOI: $10.1590 / \mathrm{S} 0100-736 \mathrm{X} 2016000200011$

\title{
Physiologic parameters in female Red-billed curassows (Crax blumenbachii) in rehabilitation ${ }^{1}$
}

\author{
Guilherme A. Marietto-Gonçalves ${ }^{2 *}$, Mayra T.A. Martins², Katiane L. Souza², Regina \\ K. Takahira ${ }^{2}$, Roberto C. Gonçalves ${ }^{2}$ and Raphael L. Andreatti Filho ${ }^{2}$
}

\begin{abstract}
Marietto-Gonçalves G.A., Martins M.T.A., Souza K.L, Takahira R.K., Gonçalves R.C. \& Andreatti Filho R.L. 2016. Physiologic parameters in female Red-billed curassows (Crax blumenbachii) in rehabilitation. Pesquisa Veterinária Brasileira 36(2):131135. Laboratório de Ornitopatologia, Departamento de Clínica Veterinária, Faculdade de Medicina Veterinária e Zootecnia, Universidade Estadual Paulista, Cx. Postal 560, Distrito de Rubião Júnior, Botucatu, SP 18618-000, Brazil. E-mail: gmarietto@hotmail.com

The present paper reports blood gas analysis, hematologic and micro bacteriologic information on four female Red-billed curassows, rescued from illegal wild animal trading, that were undergoing habilitation for reintroduction into the wild through Projeto Centrofauna/Botucatu-SP. There is a lack of physiological data on this species, endemic to the region of Atlantic Forest (Mata Atlântica), now under threat of extinction. This lack of information makes the clinical evaluation of these birds very difficult and has a direct and adverse effect on any of these birds received for medical treatment in hospitals, veterinary clinics and centers for research and conservation, as well as in reintroduction centers.
\end{abstract}

INDEX TERMS: Red-billed curassow, Crax blumenbachii, physiological parameters, cloacal microbiota, animal health.

RESUMO.- [Parâmetros fisiológicos em fêmeas de Mutum do Sudeste (Crax blumenbachii) em reabilitação.] 0 presente artigo reporta dados inéditos de análise hemogasométrica, hematológica e bacteriológica de quatro fêmeas de Mutum do Sudeste, resgatadas do tráfico ilegal de animais silvestres e em processo de habilitação e reintrodução para vida-livre pelo Projeto Centrofauna, Botucatu/ SP. Na literatura há uma falta de dados fisiológicos sobre esta espécie, endêmica da região da Mata Atlântica e ameaçada de extinção. Esta falta de informação faz com que avaliações clínicas nesta espécie aviária sejam muito difíceis de interpretar, causando um efeito direto e negativo nestas aves para a realização de tratamento médico em hospitais, clínicas veterinárias, centros de pesquisa e/ou conservação, bem como centros de reintrodução.

TERMOS DE INDEXAÇÃO: Mutum do Sudeste, Crax blumenbachii, parâmetros fisiológicos, microbiota cloacal, saúde animal.

\footnotetext{
${ }^{1}$ Received on June 2, 2015.

Accepted for publication on December 29, 2015.

${ }^{2}$ Departamento de Clínica Veterinária, Faculdade de Medicina Veterinária e Zootecnia, (FMVZ), Universidade Estadual Paulista "Júlio de Mesquita Filho" (Unesp), Cx. Postal 560, Distrito de Rubião Júnior, Botucatu, SP 18618-000, Brazil. *Corresponding author: gmarietto@hotmail.com
}

\section{INTRODUCTION}

The southeastern Curassow (Crax blumenbachii Spix, 1825) is a Brazilian bird belonging to the Cracídae family (Ordem Craciformes - ex Galliformes) that originally was found in the states of Rio de Janeiro, Espírito Santo, Minas Gerais, and Bahia, in woods and forests up to an altitude of $500 \mathrm{~m}$, which form part of the Atlantic Forest (Rodriguez-Mahecha et al. 2005, Sigrist 2009). Nowadays, C. blumenbachii is found free living only in the Sooretama Biological Reserve and in the Biological Reserve of the Companhia Vale do Rio Doce in Espirito Santo, the Ecological Reserve of Una, the APA Pratisi State, the Mount Pascoal National Park, and in the Discovery National Park in the State of Bahia. There have been some exemplars reintroduced into the Rio Doce State Park in Minas Gerais (Bencke et al. 2006), where one estimates that no more than 249 wild individuals are present (Birdlife International 2007, Birdlife International 2008).

It is estimated that the population has had an average decline of 1 to $9 \%$, chiefly due to deforestation and illegal hunting (Birdlife International 2012). This bird is now considered a species under worldwide threat of extinction (Bleul et al. 2007). In the wild, C. blumenbachii, as well as other species of curassow, has an important biological function in seed scattering and plays a fundamental role in 
maintaining the tropical forest by the dispersion of its favorite plants, ${ }^{7}$ especially the fruit of the Mystaceae family, which are very common in the area which this bird inhabits. $C$. blumenbachii also helps to distribute fleshy fruits, seedlings, small prey and hard seeds (IBAMA 2004, Bruno 2008).

In spite of the extreme threat of extinction of these birds, biological data on normal physiological standards for them are rare in the literature. This makes veterinary examinations very difficult, what may compromise conservation programs aimed at recuperation of the species, in the wild and in captivity. Given the concept that to preserve something, it is necessary to know enough about, this article presents information on body form, blood and serum values, biochemical and microbiological findings, as well as blood gas data of four captive C. blumenbachii females (Fig.1). They were apprehended by the São Paulo State Environmental Police, as victims of illegal wild animal trade. At the moment they are in the process of rehabilitation of the Centro-Fauna Project, Botucatu/SP.

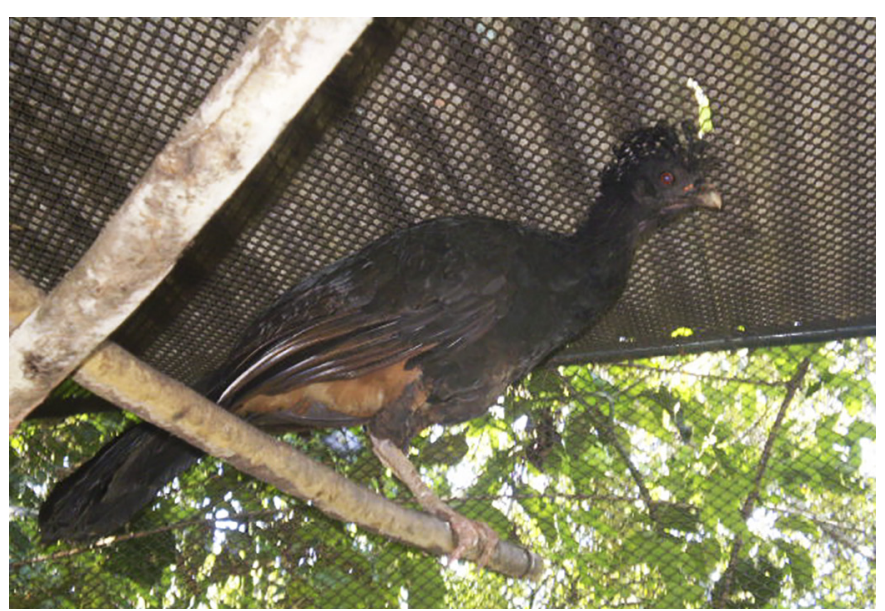

Fig.1. Female red-billed curassaw (Crax blumenbachii) is different from the male (which is totally black with a white breast and a red fleshy structure at the base of the Bill). Female is rusty black with a showy tuft heavily barred with white. Its abdomen is rusty red, the beak grey with a black base and its feathers have a reddish tinge (Rodriguez-Mahecha et al. 2005, Bruno 2008).

\section{MATERIALS AND METHODS}

All procedures were done within 10 minutes. Firstly, the birds were physically confined, and temperature red with an analog thermometer. They were then weighed on a digital scale reading up to $6 \mathrm{~kg}$ (Toledo do Brazil Indústria de Balanças Ltda, São Bernardo/SP). Auscultation of the lungs was done for abnormal sounds representing possible respiratory disturbances. Finally the superficial pectoral muscle was palpated to evaluate body mass (scoring done as shown in Figure 2).

Along with the process described above, blood samples were drawn by puncture of the brachial vein; these samples were immediately divided into three fractions for different examinations: heparinized blood for a hemogram, [0.7mL], unprocessed blood for blood gas determination $[0.3 \mathrm{~mL}]$, and serum for biochemical and serological measurements $[1 \mathrm{~mL}]$. A cloacal swab was done to identify any aerobic Gram negative Enterobacteria possibly present in the cloacal microflora of these birds.

The blood gas measurements were performed with a portable clinical analyzer I-STAT ${ }^{\circledast}$ (Abbott Laboratories, USA); they were

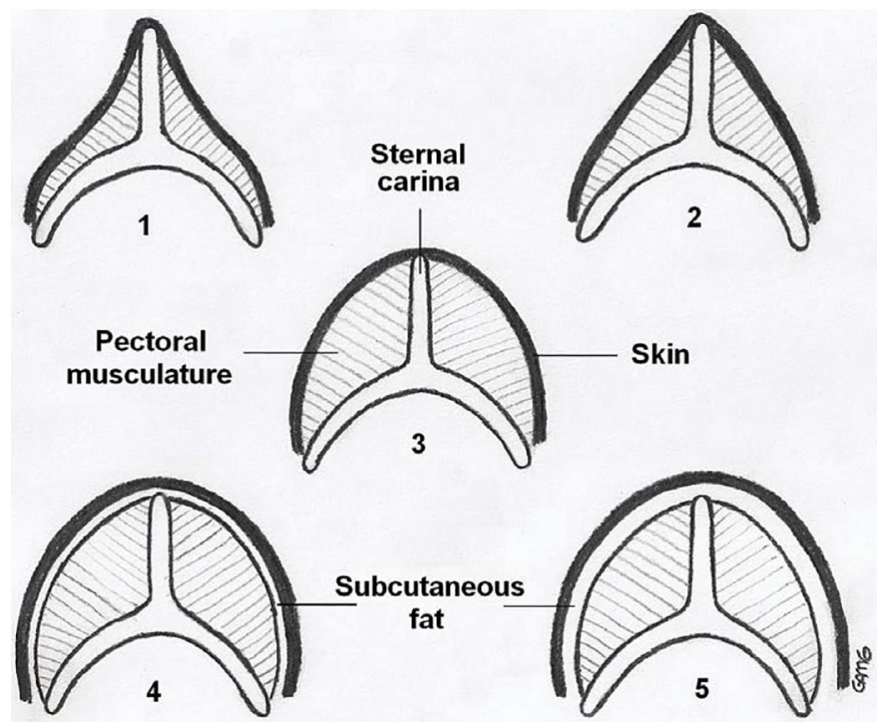

Fig.2. Physical score parameters used in this study. (Body score classification: Score 1: Little muscle mass and the external crest is prominent; Score 2: Muscle mass is present and external crest is palpable; Score 3: Muscular mass more significant, leaving only the extremity of the external crest palpable; Score 4: Muscle mass not palpable and the extreme end of the external crest palpable only with difficulty; Score 5: Both muscle mass and external crest not capable of palpation.)

done immediately after blood collection using a CG8+ (Abbout Laboratories, USA) cartouche into which two drops of venous blood were instilled. The instrument evaluated the specimen and gave the result in about 3 minutes.

For the hemogram, after blood collection, a blood smear was done from the samples, without contact with anticoagulant, to give less cellular lysis, better morphological preservation and less platelet agglutination (Green \& Blue McLendon 2000). As stated, we used heparin to condition the samples, as this preservative can be used for both hemogram determination as well as for genetic and biochemical analysis (Thrall 2007).

The blood smears were made using a small drop of blood without anticoagulant on one end of a microscope slide, and with the use of a slide extensor (positioned at $45^{\circ}$ ), the drop was spread out. After air drying, the smears were stained using Wright stain, as per Schalm (1965), for 10 minutes. They were then covered with distilled water until a reverse meniscus formed, for more than 15 minutes. They were then rinsed in running water to remove excess stain and afterwards heat dried. In the blood smear all cellular types were seen, with good morphological detail: presence or not of inclusions and blood parasites was noted, and a differential leukocyte count was done.

The hematocrit was obtained using a microhematocrit. Capillary non-heparinized tubes were filled to two thirds of their volume with the blood samples. These were heat sealed, and centrifuged at 15,000 rpm for 5 minutes. The capillary tubes were read on a standardized scale and the value obtained in percentages (Bierer et al. 1963). The plasma was examined for color alterations or turbidity due to hemolysis and /or lipemia.

Additionally, with the capillary tube we obtained the total plasma protein levels (TP). The tube was divided and the plasma placed in a refractometer for evaluation. Hemoglobin measurement was done by the cyanmethemoglobin method. The principle of this method is the oxidation of ferric iron by the action of potassium ferrocyanide present in Drabkin's Reagent (Thrall 2007). Quantization of the hemoglobin cyanide formed was done by colorimetry. 
Red blood cells and the leukocyte and platelets numbers were done using a Neubauer Hemacytometer chamber. Two mL of toluidine Blue $(0.01 \%)$ was added to $20 \mu \mathrm{L}$ of blood and allowed to rest for 10 minutes to color the cells. The Neubauer chamber was then filled, the cells were allowed to sediment for 15 minutes and the reading was taken. The red blood cells were counted in the same quadrants used for mammals (five quarters of a central square) at 400x magnification, and the value found was multiplied by a factor of 5,050. White blood cells and platelets were counted separately in the same quadrants used for counting leukocytes in mammals (four large quadrants) and the value found was multiplied by 252.5 .

The red blood cell indices MCV and MCHC were obtained using the following mathematical calculations:

MCV (fL) $=\mathrm{Ht}(\%) /$ red blood cells $\left(\mathrm{x} 10^{6} / \mathrm{uL}\right) * 10$

MCHC $(\mathrm{g} / \mathrm{dL})=$ hemoglobin $(\mathrm{g} / \mathrm{dL}) / \mathrm{Ht}(\%) * 100$

For biochemical evaluations, $70 \mu \mathrm{L}$ of serum was used for each analysis, and the doses were found using the Cobas Mira Plus da Roche (Roche Diagnostics, Germany) equipment with specific kits for each Ebram test (Ebram, Brazil).

Serological tests for Pullorum disease and Mycoplasmosis were done using the rapid serum agglutination assay (RSA). For Newcastle Disease, the beta hemaglutination -inhibition method was used as described by Santos \& Silva (2000). In the RSA we used the commercially available antigen Pulor Teste ${ }^{\circledR}$ for Salmonella Pullorum, the Myco-Galli Teste ${ }^{\circledR}$ for Mycoplasma gallisepticum and the Synovitest ${ }^{\circledR}$ for M. synoviae (Biovet, Brazil). For each $50 \mu \mathrm{L}$ of antigen, we used $50 \mu \mathrm{L}$ of serum which was mixed with a glass rod in the SAR reading plate.

After homogenization of the serum with the antigen, gentle rotatory movements of the reading plate were made for two minutes. Samples which showed agglomerations during this time were considered positive.

For each test we used known positive control samples from a domestic chicken (Gallus gallus domesticus).A live virus strain (La Sota, New vac $\mathrm{LS}^{\circledR}$, Fort Dodge, Brazil), was used for the IH test. One unit of hemaglutinate (UHA) $=1 / 8$ (titration ascertained using the Hemaglutination test HA). For the IH we used 4 UHA. In each round bottom well of the plate, with space for 8 samples, $50 \mu \mathrm{L}$ of phosphatase saline was distributed in a dozen linear wells. In the first wells $50 \mu \mathrm{L}$ of serum was placed, being serially diluted from the first to the twelfth well. This last dilution was discarded. Following this, $50 \mu \mathrm{L}$ of virus was placed in each well and, after homogenization, the plate was allowed to rest for 40 minutes at $5^{\circ} \mathrm{C}$.

After this, $50 \mu \mathrm{L}$ of red blood cell solution and $1 \%$ red blood cells (of the domestic chicken Gallus gallus domesticus) were added and after homogenization, left to rest once again for $40 \mathrm{minu}-$ tes at $5^{\circ} \mathrm{C}$. Positive samples were considered to be those in which the inhibition of hemaglutination was higher than the highest dilution of the agglutinate (1/8).

The fecal samples collected from the cloacal swabs were initially pre-enriched by incubation in study tubes containing $10 \mathrm{~mL}$ of peptonated water at $40^{\circ} \mathrm{C}$ for 24 hours. Following this, $1 \mathrm{~mL}$ of the pre-enriched cultures were added to tubes of Brain Heart infusion medium, and into another Tetrathionate broth, once again being incubated at $40^{\circ} \mathrm{C}$ for 24 hours .Finally, samples were seeded onto Brilliant Green agar, MacConkey's medium and Xylose-Lisine-Desoxicolate, all being incubated at $40^{\circ} \mathrm{Cfor} 24$ hours. After these processes, the presence of distinct colony forms was assessed, and then a sample of each one was collected for biochemical identification using the method described by Holt et al. (1994).

\section{RESULTS}

Results of the hematologic evaluations, the blood gases, the biochemical and microbiological results are presented in

Table 1. Hematologic, serum biochemical and haemogasometrics values of four female Crax blumenbachii

\begin{tabular}{|c|c|c|c|c|c|}
\hline Parâmetros & 1 & 2 & 3 & 4 & Mean \pm SP \\
\hline \multicolumn{6}{|l|}{ General data } \\
\hline $\mathrm{BT}\left({ }^{\circ} \mathrm{C}\right)$ & 40 & 40 & 40,2 & 40,4 & $40.15 \pm 0.16$ \\
\hline Weight (KG) & 3 & 3.2 & 3.28 & 3.1 & $3.14 \pm 0.12$ \\
\hline BS & 3 & 3 & 3 & 3 & $3 \pm 0$ \\
\hline \multicolumn{6}{|l|}{ Hematimetry } \\
\hline 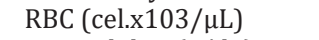 & 2.430 & 2.603 & 2.940 & 1.980 & $2.488 \pm 346$ \\
\hline Hemoglobin (g/dL) & 20.4 & 19.6 & 19.8 & 18.4 & $19.55 \pm 0.83$ \\
\hline Hematocrit (\%) & 42 & 41 & 42 & 40 & $41.25 \pm 0.95$ \\
\hline CMV (fL) & 172.8 & 180.1 & 142.8 & 202 & $174.42 \pm 24.46$ \\
\hline MCHC (\%) & 48.6 & 47 & 47.1 & 46 & $47.17 \pm 69.88$ \\
\hline $\mathrm{PT}(\mathrm{g} / \mathrm{dL})$ & 6 & 5 & 4 & 4.4 & $4.85 \pm 0.86$ \\
\hline \multicolumn{6}{|c|}{ Leucometry } \\
\hline Leukocytes (cel. x103/ $\mu \mathrm{L}$ & 12.3 & 12.8 & 14.8 & 11.3 & $12.8 \pm 1.27$ \\
\hline Heterophils (\%) & 83 & 78 & 64 & 65 & $72.5 \pm 9.46$ \\
\hline Lyn & 6 & 9 & 16 & 12 & $10.75 \pm 4.27$ \\
\hline Eosin & 1 & 1 & 0 & 1 & $0.75 \pm 0.5$ \\
\hline Basop & 0 & 0 & 4 & 8 & $3 \pm 3.82$ \\
\hline Monocytes (\%) & 10 & 12 & 16 & 14 & $13 \pm 2.58$ \\
\hline \multicolumn{6}{|l|}{ Hemogasometry } \\
\hline $\mathrm{pH}$ & 7.12 & 7.15 & 7.16 & 7.02 & $7.11 \pm 0.05$ \\
\hline PCO2 (mmHg) & 44.8 & 61.7 & 50.2 & 73.9 & $57.65 \pm 12.92$ \\
\hline $\mathrm{PO} 2(\mathrm{n}$ & 45 & 37 & 47 & 43 & $43 \pm 4.32$ \\
\hline BEecf & -14 & -7 & -11 & -12 & $-11 \pm 2.94$ \\
\hline $\mathrm{HCO}-(\mathrm{mmol} / \mathrm{L})$ & 14.3 & 20.9 & 17.4 & 18.4 & $17.75 \pm 2.73$ \\
\hline TCO2 (mmol/L) & 15 & 22 & 19 & 20 & $19 \pm 2.94$ \\
\hline SO2 (\%) & 55 & 43 & 60 & 42 & $50 \pm 8.9$ \\
\hline $\mathrm{Na}(\mathrm{m}$ & 147 & 154 & 143 & 156 & $150 \pm 6.05$ \\
\hline$(\mathrm{m}$ & 7.9 & 6.9 & 6.6 & 7.5 & $7.22 \pm 0.58$ \\
\hline iCa (mmol/L) & 1.23 & 1.28 & 1.13 & 1.3 & $1.23 \pm 0.07$ \\
\hline Glicosis (mg/dL) & 312 & 248 & 376 & 381 & $329.25 \pm 62.61$ \\
\hline \multicolumn{6}{|l|}{ Serum biochemical } \\
\hline Urea (mg/dL) & 7 & 7 & 8 & 5 & $6.75 \pm 1.26$ \\
\hline Creatinine (mg/dL) & 0.1 & 0.2 & 0.1 & 0.2 & $0.15 \pm 0.06$ \\
\hline $\mathrm{d}(\mathrm{mg} / \mathrm{dL})$ & 5.1 & 4.2 & 5.3 & 4.4 & $4.75 \pm 0.53$ \\
\hline ALT (UI/L) & 2 & 2 & 3 & 3 & $2.50 \pm 0.58$ \\
\hline AST (UI/L) & 22 & 11 & 12 & 28 & $18.25 \pm 8.18$ \\
\hline ALP (UI/L) & 70 & 33 & 39 & 52 & $48.50 \pm 16.38$ \\
\hline GGT (UI/L) & 6.5 & 2 & 2.3 & 10.4 & $5.30 \pm 3.97$ \\
\hline Total Protein (g/dL) & 4.8 & 5.9 & 6.4 & 4.6 & $5.43 \pm 0.87$ \\
\hline Albumine $(\mathrm{g} / \mathrm{dL})$ & 2 & 2.1 & 2.2 & 1.9 & $2.05 \pm 0.13$ \\
\hline & 2.8 & 3.8 & 4.4 & 2.7 & $3.43 \pm 0.82$ \\
\hline Calcium (mg/dL) & 10.1 & 10.2 & 11.5 & 7.5 & $9.83 \pm 1.68$ \\
\hline Phosphorus (mg/dL) & 4.7 & 5.75 & 6.4 & 7.43 & $6.07 \pm 1.15$ \\
\hline
\end{tabular}

$\mathrm{SD}=$ Standart deviation, $\mathrm{BT}=$ Body temperature, $\mathrm{BS}=$ Body Score, $\mathrm{RBC}=$ red blood cells, $\mathrm{MCV}=$ Mean corpuscular volume, $\mathrm{MCHC}=$ Mean corpuscular hemoglobin concentration, $\mathrm{PT}=$ Plasmatic proteins, $\mathrm{PO} 2=$ 0xygen pressure, $\mathrm{PCO} 2=$ Carbonic gas pressure, $\mathrm{BE}=$ Base excess, $\mathrm{HCO} 3-=\mathrm{Bi}-$ carbonate, $\mathrm{TCO} 2=$ Total carbon dioxide, $\mathrm{SO} 2=$ 0xygen saturation, $\mathrm{iCa}=$ Ionized calcium, ALT = Alanine aminotransferase, AST = Aspartate aminotransferase, $\mathrm{ALP}=$ Alkaline phosphatase.

Table 2. Aerobic Gram-negative Enterobacterias isolated by cloacal swab from four red-billed curassow females (Crax blumenbachii)

\begin{tabular}{lcc}
\hline Bacterial species & Positive (T) & Prevalence (\%) \\
\hline Escherichia coli & $4(4)$ & 100 \\
Serratia marcensces & $3(4)$ & 75 \\
Proteus vulgaris & $4(4)$ & 100 \\
Proteus mirabilis & $2(4)$ & 50 \\
Enterobacter aerogenes & $1(4)$ & 25 \\
Citrobacter freudii & $1(4)$ & 25 \\
Klebsiella pneumoniae & $2(4)$ & 50 \\
Klebsiella oxytoca & $1(4)$ & 25
\end{tabular}

$\mathrm{T}=$ total number of samples analyzed. 
Table 1 and 2. There was no serological detection of any of the agents searched for in this study.

\section{DISCUSSION}

The physical evaluation showed that all the birds had a good body score, with an acceptable weight, as the mean body weight for an adult Crax blumenbachii varies from 3.0$3.5 \mathrm{~kg}$ (Sigrist 2009). They all had a normal temperature, which for bird species varies from 40 to $42^{\circ} \mathrm{C}$. Our four birds showed adult female characteristics, and we considered them to be sexually mature and at least three years of age. On respiratory examination, no abnormal sounds (such as rales, rhonchi or whistling) were heard, indicating there were no respiratory problems. For this reason, we concluded that the blood gas parameters which were found are close to or normal (keeping in mind the stress to the birds caused by the procedure). There are no blood gas data available in the literature for this particular species of bird.

Blood gas measurement has a wide clinical application, as one can quantify respiratory system abnormalities based on the $\mathrm{pH}$ values of the blood, the partial pressure of carbon dioxide and oxygen. Additionally it is possible to deduce carbonate values, due to the acid-base organic dis-equilibrium in the blood gas concentrations, However, other parameters also may be evaluated (Sobiech et al. 2005, Zavorsky et al. 2007).

In this study, we used venous blood obtained easily due to its anatomical location. Ideally, arterial blood would be used to evaluate pulmonary function. However, venous blood still gives reasonably confident values, in spite of not allowing measurement of pulmonary oxygen carrying capacity (Sobiech et al. 2005, Bleul et al. 2007, Zavorsky et al. 2007, Mota \& Queiroz 2010).

We were unable to find any reference values for hematologic standard and biochemical serum standard for this species, to compare with our values. However, given the healthy clinical appearance of the birds in our study, we consider our values to be representative of normal values. We do not know if there is a difference between the sexes in these values, as we did not evaluate any males. Similarly, we do not know if these values differ with age.

Escherichia coli were found in all (100\%) of the birds in this study. Santos et al. (2010) reported this bacteria in one captive individual of $C$. blumenbachii. The finding of this organism in the intestinal apparatus of diverse domestic bird species as well as in wild birds is considered normal (Barnes et al. 2008). The E. coli presence is report in captive Ortalis guttata, Penelope obscura, Pipile pipile, P. jacutinga, C. fasciolata, Pauxi tuberosa (Santos et al. 2010) and P. mitu (Saidenberg et al. 2013).

With our observations, it is possible to speculate that $E$. coli may be a part of the normal bacterial flora of $C$. blumenbachii, at least in captivity, although there are no data available in wild birds. Proteus vulgaris was also isolated for $100 \%$ of our birds under study. The occurrence of this species as well as others which we isolated in our study has not been reported in the literature. For this reason, we do not know if these organisms are normal in C. blumenbachii, or if they represent contaminants. However, it is known that all the species we found are commonly encountered in the industrial avian environment (Chernaki-Leffer et al. 2002, Segabinazi et al. 2005).

Due to the small number of birds available for our study, we could not do a precise statistical evaluation. As well, we were unable to obtain other birds from rehabilitation centers, breeders or zoological parks to increase the number of birds evaluated, which would result in more precise analysis of the results obtained.

The few sites which have birds available are very far away from the laboratories where the analyses were performed. It is imperative that the blood gas analysis and the hematological studies be done immediately after collection; otherwise the results cannot be relied upon.

\section{CONCLUSION}

Escherichia coli can be considered a part of the normal microflora of Crax blumenbachii; however, there are few details available for the species. New studies need to be done to identify the microbial flora and physiological parameters in captive members as well as in wild birds of this species. These studies are necessary to quantify measurements for the determination of standard values for C. blumenbachii, a species which is on the brink of extinction. As this species is also very important for the equilibrium of the Atlantic Forest ecosystem, it must become better understood for success in its conservation as a valuable biological entity.

\section{REFERENCES}

Barnes H.J., Nolan L.K. \& Valliancourt J.P. 2008. Colibacillosis, p.775-732. In: Saif Y.M, Fadly A.M., Glisson J.R., McDougald L.R., Nolan L.K. \& Swayne D.E. (Eds), Diseases of Poultry. Vol.12. Blackwell Publishing, Ames.

Bencke A., Mauricio G.N., Develey P.F. \& Goerck J.M. 2006. Áreas Importantes para a Conservação das Aves no Brasil. 1. Estados de Domínio da Mata Atlântica. SAVE Brasil, São Paulo, SP. 341p.

Bierer B.W., Thomas J.B., Roebuck D.E., Powell H.S. \& Eleazer T.H. 1963. Hematocrit and sedimentation rate values as an aid in poultry disease diagnosis. J. Am. Vet. Med. Assoc. 143:1096-1098.

Birdlife International 2007. Threatened Birds of the World. Available at <http://www.birdlife.org> Access in July 2013.

Birdlife International. 2008. Crax blumenbachii. In: IUCN 2011. IUCN Red List of Threatened Species. Disponível em <http://www.iucnredlist. org> Access in June 2013.

Birdlife International 2012. Species factsheet: Crax blumenbachii. Available at <http://www.birdlife.org> Access in June 2013.

Bleul U., Lejeune B., Schwantag S. \& Kähn W. 2007. Blood gas and acid-base analysis of arterial blood in 57 newborn calves. Vet. Rec. 161:688-691.

Bruno S.F. 2008. 100 animais ameaçados de extinção e o que você pode fazer para evitar. Ediouro, Rio de Janeiro. 144p.

Chernaki-Leffer A.M., Biesdorf S.M., Almeida L.M., Leffer E.V.B. \& Vigne F. 2002. Isolamento de enterobactérias em Alphitobius diaperinus e na cama de aviários noroeste do estado do Paraná, Brasil. Braz. J. Poult. Sci. 4(3):243-247.

Green R. \& Blue McLendon A. 2000. Ratite hematology, p.1201-1206. In: Feldman B.F., Zink J.G. \& Jain N.C. (Eds), Schalm's Veterinary Hematology. Vol.5. Lippincott Williams, Philadelphia.

Holt J.G., Krieg N.R., Sneath P.H.A., Staley J.T. \& Williams S.T. 1994. Bergey's Manual of Determinative Bacteriology. Vol.9. Williams and Wilkins, Baltimore. 787p.

IBAMA 2004. Plano de ação para conservação do Mutum do Sudeste Crax Blumenbachii. Série Espécies Ameaçadas, Vol.1. Available at <http:// www.ib.usp.br/ lfsilveira/pdf/1_2004_blumenbachii.pdf> Access in June 2013. 
Mota I.L. \& Queiroz R.S. 2010. Distúrbios do equilíbrio ácido básico e gasometria arterial: uma revisão crítica. Revista Digital, Buenos Aires, 14. Availabale at <http://www.efdeportes.com/efd141/equilibrio-acido-basico-e-gasometria-arterial.htm> Access in April 2013.

Rodríguez-Mahecha J.V., Hugues N., Nieto O. \& Franco A.M. 2005. Paujiles, Pavones, Pavas and Guacharacas Neotropicales. Conservatión Internacional, Bogotá, CO. 98p.

Saidenberg A.A.B., Allegretti L., Astolfi-Ferreira C.C.S., Ferreira J.P., Almeida M.A. \& Raso T.F. 2013. Alguns genes de virulência de Escherichia coli isoladas de mutuns-do-nordeste (Pauxi mitu) sadios no Brasil. Pesq. Vet. Bras. 33:523-527.

Santos C.H.C. \& Silva E.N. 2000. Métodos de diagnósticos laboratoriais microbiológicos e sorológicos, p.173-182. In: Berchieri Júnior A. \& Macari M. (Eds).,Doenças das Aves. Fundação APINCO de Ciência e Tecnologia Avícola, Campinas, SP.

Santos H.F., Flôres M.L., Lara V.M., Sá e Silva M., Battisti L. \& Lovato L.T. 2010. Microbiota cloacal aeróbia de cracídeos cativos no Rio Grande do Sul e sua susceptibilidade á antimicrobianos. Pesq. Vet. Bras. 30:1077-1082.
Segabinazi S.D., Flôres M.L., Barcelos A.S., Jacobsen G. \& Eltz R.D. 2005. Bactérias da família Enterobacteriaceae em Alphitobius diaperinus oriundos de granjas avícolas dos Estados do Rio Grande do Sul e Santa Catarina, Brasil. Acta Scient. Vet. 33:51-55.

Schalm O.W. 1965. Veterinary Hematology. Lea and Febiger, Philadelphia. $664 p$.

Sigrist T. 2009. The Avis Brasilis Field Guide to the Birds of Brazil: especies accounts. Avibrasilis, São Paulo, SP. 305p.

Sobiech P., Stopyra A., Kuleta Z., Zbanyszek M. \& Milewski M. 2005. Acidbase balance parameters of arterial, venous and capillary blood in sheep. Bull. Vet. Inst. Pulawy 49:125-127.

Thrall M.A. 2007. Hematologia e bioquímica clínica veterinária. Roca, São Paulo. 592p.

Zavorsky G.S., Cao J., Mayo N.E., Gabbay R. \& Murias J.M. 2007. Arterial versus capillary blood gases: a meta-analysis. Resp. Physiol. Neurobiol. 155:268-279. 